\title{
Actinoplanes abujensis sp. nov., isolated from Nigerian arid soil
}

\author{
Anil Sazak, Nevzat Sahin and Mustafa Camas \\ Department of Biology, Faculty of Art and Science, Ondokuz Mayıs University, \\ 55139 Kurupelit-Samsun, Turkey
}

Correspondence

Nevzat Sahin

nsahin@omu.edu.tr
Members of the genus Actinoplanes, which was first described by Couch (1950), produce motile spores with spherical, cylindrical, digitate, lobate, bottle or flaskshaped or very irregular sporangia by tufts of polar flagella. Aerial hyphae are scant. Actinoplanes strains are also characterized by a number of chemical markers, including the presence of meso- and hydroxy-diaminopimelic acid in the whole-cell peptidoglycan, and contain arabinose and xylose as characteristic sugars, MK- $9\left(\mathrm{H}_{4}\right)$ as the predominant menaquinone and a genomic DNA G $+\mathrm{C}$ content of 67-76 mol\% (Goodfellow \& Cross, 1984; Kothe, 1987; Vobis, 1989). Phosphatidylethanolamine is the diagnostic phospholipid (Kämpfer et al., 2007). Predominant fatty acids are iso-/anteiso-branched and monounsaturated fatty acids and/or cis-9,10-octadecanoic acid. The first detailed phenotypic and chemotypic analysis of the genus was provided by Goodfellow et al. (1990), who reported that chemical and numerical taxonomic data supported the integrity of the genus. A comprehensive phylogenetic analysis, based on $16 \mathrm{~S}$ rRNA gene sequences of members of the genus, was given by Tamura \& Hatano (2001). At the time of writing, the genus Actinoplanes comprised 28 species with validly published names.

Abbreviation: ISP, International Streptomyces Project.

The GenBank/EMBL/DDBJ accession number for the 16S rRNA gene sequence of Actinoplanes abujensis $\mathrm{A} 4029^{\top}$ is $\mathrm{HO} 157185$.

A supplementary table and a supplementary figure are available with the online version of this paper.
During a study on the ecological diversity of actinomycetes from different soils, strain $\mathrm{A} 4029^{\mathrm{T}}$ was isolated on Gauze's medium no. 2 (Gauze et al., 1957) supplemented with cycloheximide $\left(50 \mu \mathrm{g} \mathrm{ml}^{-1}\right)$, nystatin $\left(50 \mu \mathrm{g} \mathrm{ml}^{-1}\right)$, nalidixic acid $\left(10 \mu \mathrm{g} \mathrm{ml}^{-1}\right)$ and novobiocin $\left(10 \mu \mathrm{g} \mathrm{ml}^{-1}\right)$ incubated at $28{ }^{\circ} \mathrm{C}$ for 21 days, from soil samples collected in an arid area, Abuja, Nigeria. The isolate was purified and maintained on glucose-yeast extract-malt extract (GYME; $4 \mathrm{~g}$ glucose, $4 \mathrm{~g}$ yeast extract, $10 \mathrm{~g}$ malt extract, $1 \mathrm{l}$ distilled water, $\mathrm{pH}$ 7.2) agar medium and preserved as a suspension of mycelial fragments in glycerol $(20 \%, \mathrm{v} / \mathrm{v})$ at $-20{ }^{\circ} \mathrm{C}$.

The morphological and physiological characteristics of strain $\mathrm{A} 4029^{\mathrm{T}}$, Actinoplanes brasiliensis DSM $43805^{\mathrm{T}}$ and Actinoplanes deccanensis DSM $43806^{\mathrm{T}}$ were studied together. Morphological characteristics were determined after incubation for 14 days at $28{ }^{\circ} \mathrm{C}$ on various media described by Shirling \& Gottlieb (1966): yeast extract-malt extract [International Streptomyces Project (ISP) 2], oatmeal (ISP 3), inorganic salt-starch (ISP 4), glycerol-asparagine (ISP 5), peptone-yeast extract-iron (ISP 6), tyrosine (ISP 7), modified Bennett's agar (MBA; Jones, 1949), Czapek's agar, trypticase soy agar (TSA) and nutrient agar (NA; Difco). The National Bureau of Standards Color Name Charts (Kelly, 1964) was used for determining colour designation and names. Growth at different temperatures was determined on GYME medium incubated at $10,20,37$ and $45{ }^{\circ} \mathrm{C} . \mathrm{NaCl}$ tolerance was examined on GYME medium prepared with 1 , 2, 3, 4 and $5 \%(\mathrm{w} / \mathrm{v}) \mathrm{NaCl}$. Decomposition of various compounds was examined using the basal medium 
recommended by Williams et al. (1983). In addition, degradation of RNA $(0.5 \%, \mathrm{w} / \mathrm{v})$, chitin $(0.4 \%, \mathrm{w} / \mathrm{v})$ and Tweens 20 and $80(1 \%, \mathrm{w} / \mathrm{v})$ was examined using media and methods described by Goodfellow et al. (1979), Hsu \& Lockwood (1975) and Nash \& Krenz (1991), respectively. Carbon source utilization was tested using carbon source utilization (ISP 9) medium (Shirling \& Gottlieb, 1966) supplemented with a final concentration of $1 \%$ of the tested carbon sources and $0.1 \%$ propionic and succinic acids. Nitrogen source utilization was examined using the basal medium recommended by Williams et al. (1983) supplemented with a final concentration of $0.1 \%$ of the nitrogen sources tested. Tests in the commercial API 20E and API ZYM systems (bioMérieux) were performed according to the manufacturer's instructions. The ability of strain $\mathrm{A} 4029^{\mathrm{T}}$ to inhibit the growth of 16 micro-organisms, i.e. Grampositive and -negative bacteria, yeast and fungi, was observed using an overlay technique described by Williams et al. (1983). Spot-inoculated colonies on MBA plates were inverted over $2 \mathrm{ml}$ chloroform for $40 \mathrm{~min}$. Killed colonies were overlaid with 5-7 ml sloppy modified Bennett's broth inoculated with the test organisms. Zones of inhibition were scored as positive results after $24 \mathrm{~h}$ at $28{ }^{\circ} \mathrm{C}$.

Cells of strain $\mathrm{A} 4029^{\mathrm{T}}$ stained Gram-positive. Good growth was observed on most of the tested media. The colour of the substrate mycelium was moderate to deep orange. A strong brown soluble pigment was formed on ISP 7. Cultural characteristics of strain $\mathrm{A} 4029^{\mathrm{T}}$ in all tested media are presented in Table 1. The physiological properties that differentiated strain $\mathrm{A} 4029^{\mathrm{T}}$ from A. brasiliensis DSM $43805^{\mathrm{T}}$ and $A$. deccanensis DSM $43806^{\mathrm{T}}$ are shown in Table 2. A. brasiliensis DSM $43805^{\mathrm{T}}$ and A. deccanensis DSM $43806^{\mathrm{T}}$ could decompose Tween 20 , utilize amygdalin, $\mathrm{D}(-)$ arabinose, $\mathrm{D}(-)$ fructose, $\mathrm{D}(-)$ galactose, dextrin, mannitol, melibiose, myo-inositol, sucrose and xylose as sole sources of carbon, and utilize L-hydroxyproline and Lmethionine as sole sources of nitrogen, but strain $\mathrm{A} 4029^{\mathrm{T}}$ could not. Other physiological and biochemical features that differentiated strain A4029 $9^{\mathrm{T}}$, A. brasiliensis DSM $43805^{\mathrm{T}}$ and A. deccanensis DSM $43806^{\mathrm{T}}$ included $\mathrm{NaCl}$ ranges for growth, nitrate reduction, patterns of carbon utilization and antimicrobial activities against Bacillus pumilus NRRL BD-142 and Staphylococcus aureus ATCC 33862.

Preparation of genomic DNA and PCR amplification of the 16S rRNA gene were carried out according to Chun \& Goodfellow (1995). Nearly complete 16S rRNA gene sequences were determined for strain $\mathrm{A} 4029^{\mathrm{T}}$ (1490 bp) by using an ABI PRISM 3730XL automatic sequencer. The identification of phylogenetic neighbours and the calculation of pairwise $16 \mathrm{~S}$ rRNA gene sequence similarities were achieved using the EzTaxon server (http://www.eztaxon. org/; Chun et al., 2007). CLUSTAL W version 1.8 (Thompson et al., 1994) was used to align the sequence of strain A4029 ${ }^{\mathrm{T}}$ with those of related taxa retrieved from public databases. Phylogenetic trees were inferred using the neighbour-joining (Saitou \& Nei, 1987) and maximum-parsimony (Fitch, 1971) tree-making algorithms from the program MEGA version 3 (Kumar et al., 2004), and the maximum-likelihood method (Felsenstein, 1981) from the PHYLIP suite of programs (Felsenstein, 1993). The evolutionary distance model of Jukes \& Cantor (1969) was used to generate evolutionary distance matrices for the neighbour-joining algorithm. Topologies of the resultant trees were evaluated in a bootstrap analysis (Felsenstein, 1985) based on 1000 resamplings of the neighbour-joining dataset using the CONSENSE and SEQBOOT options from the PHYLIP package.

An almost complete 16S rRNA gene sequence (1490 nt) was determined for strain $\mathrm{A} 4029^{\mathrm{T}}$; a $1481 \mathrm{nt}$ fragment was used for phylogenetic analysis and compared against $16 \mathrm{~S}$ rRNA gene sequences of members of the genus Actinoplanes. The phylogenetic tree based on the neighbour-joining algorithm showed that strain $\mathrm{A} 4029^{\mathrm{T}}$ formed a cluster with most related strain A. brasiliensis DSM $43805^{\mathrm{T}}$ at a high bootstrap resampling value $(99.0 \%$; Fig. 1). Sequence similarity calculations indicated that the closest relatives of strain A4029 ${ }^{\mathrm{T}}$ were A. brasiliensis DSM $43805^{\mathrm{T}}(98.9 \% ; 15 \mathrm{nt}$ differences at 1481 locations) and $A$. deccanensis DSM $43806^{\mathrm{T}}$ (98.0\%; $29 \mathrm{nt}$ differences at 1481 locations); lower sequence similarities $(<97.9 \%)$ were found with the type strains of all other members of the genus Actinoplanes with validly published names.

DNA-DNA relatedness values between strain $\mathrm{A} 4029^{\mathrm{T}}$ and $A$. brasiliensis DSM $43805^{\mathrm{T}}$ were performed by the Identification Service at the Deutsche Sammlung von Mikroorganismen und Zellkulturen Braunschweig, Germany. DNA was isolated using a French pressure cell (Thermo Spectronic) and purified by chromatography on hydroxyapatite as described by Cashion et al. (1977). DNA-DNA hybridization was carried out as described by De Ley et al. (1970) [incorporating the modifications described by Huß et al. (1983)] using a model Cary 100 Bio UV/VISspectrophotometer equipped with a Peltier-thermostatted $6 \times 6$ multicell changer and a temperature controller with in situ temperature probe (Varian).

The taxonomic integrity of the test strains was supported by DNA relatedness data. Strain A $4029^{\mathrm{T}}$ was determined to have $43.2 \%$ genomic DNA-DNA relatedness (based on a mean of duplicate determinations) with A. brasiliensis DSM $43805^{\mathrm{T}}$, the phylogenetically most closely related member of the genus Actinoplanes, which is clearly well below the $70 \%$ relatedness guideline proposed by Wayne et al. (1987) for the delineation of separate species.

Biomass for chemotaxonomic studies was prepared by growing strain $\mathrm{A} 4029^{\mathrm{T}}$ in GYME broth at 160 r.p.m. for 10 days at $28{ }^{\circ} \mathrm{C}$; cells were harvested by centrifugation, washed in distilled water, re-centrifuged and freeze-dried. Whole-cell hydrolysates were analysed for diaminopimelic acid isomers using TLC (Staneck \& Roberts, 1974) and for sugars using the method of Mikami \& Ishida (1983). Phospholipids were extracted and analysed by the method of Minnikin et al. (1984) as modified by Kroppenstedt \& Goodfellow (1991). The predominant isoprenoid quinones were extracted and purified by the method of Tindall 
Table 1. Cultural characteristics of strain $A 4029^{\top}$ and the most related type strains of the genus Actinoplanes on different media Strains: 1 , A4029 ${ }^{\mathrm{T}}$; 2, A. brasiliensis DSM $43805^{\mathrm{T}}$; 3, A. deccanensis DSM $43806^{\mathrm{T}}$. Symbols: +++ , abundant; ++ , moderate; + , poor.

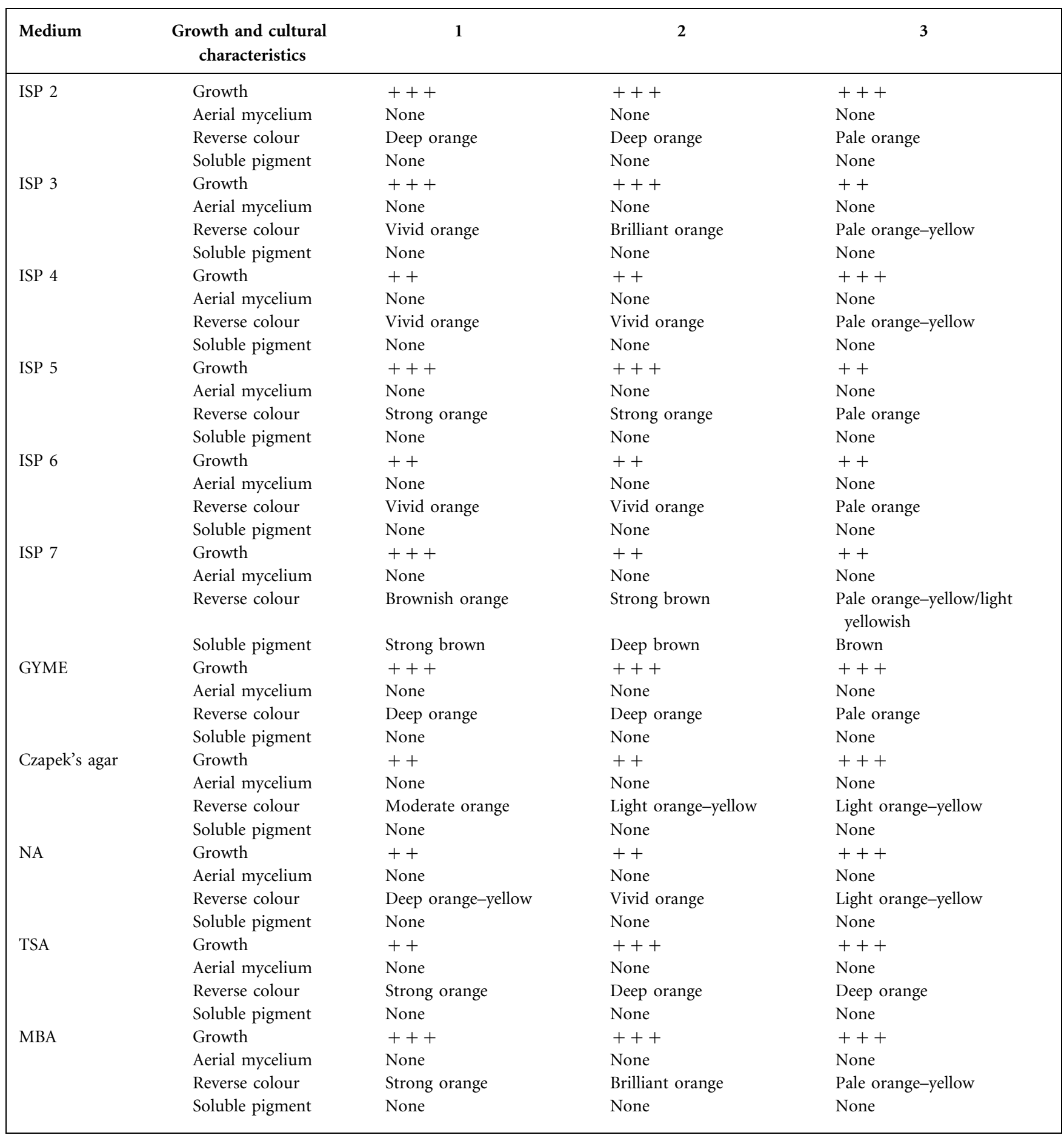

(1990a, b) and were determined by reversed-phase HPLC (Wu et al., 1989). In order to quantify whole-cell fatty acid composition, cells were grown in $20 \mathrm{ml}$ trypticase soy broth (TSB) at $28{ }^{\circ} \mathrm{C}$ with shaking at 150 r.p.m. After 5 days of incubation, $5 \mathrm{ml}$ of this starter culture was inoculated into $50 \mathrm{ml}$ TSB. The inoculated flask was incubated as before for 5 days. After harvesting by cellulose membrane filtration $(0.45 \mu \mathrm{m})$, wet cells $(200 \mathrm{mg})$ were placed in an extraction tube. Cellular fatty acids were extracted, derivatized to their fatty acid methyl esters and separated by the Microbial Identification System (MIDI; Microbial ID), utilizing an Agilent Technologies 6890N GC with a G2614A autosampler and a 6783 injector (Sasser, 1990; Kämpfer \& Kroppenstedt, 1996). Fatty acid methyl 
Table 2. Phenotypic characteristics that differentiate strain $\mathrm{A} 4029^{\top}$ from the most related members of the genus Actinoplanes

Strains: $1, \mathrm{~A} 4029^{\mathrm{T}} ; 2$, A. brasiliensis DSM $43805^{\mathrm{T}} ; 3$, A. deccanensis DSM $43806^{\mathrm{T}}$. Symbols: \pm , weak; + , positive; - , negative.

\begin{tabular}{|c|c|c|c|}
\hline Characteristic & 1 & 2 & 3 \\
\hline \multicolumn{4}{|l|}{ Degradation of: } \\
\hline Tween 20 & - & + & + \\
\hline Tween 80 & - & + & - \\
\hline \multicolumn{4}{|l|}{$\begin{array}{l}\text { Growth on sole carbon sources }(1.0 \% \text {, } \\
\text { w/v): }\end{array}$} \\
\hline $\mathrm{D}(-)$ Arabinose & - & + & + \\
\hline $\mathrm{D}(-)$ Fructose & - & + & + \\
\hline $\mathrm{D}(-)$ Salicin & - & + & - \\
\hline $\mathrm{D}(-)$ Sorbitol & - & - & + \\
\hline $\mathrm{D}(-)$ Galactose & - & + & + \\
\hline Dextrin & - & + & + \\
\hline Lactose & - & - & + \\
\hline myo-Inositol & - & + & + \\
\hline Raffinose & - & - & + \\
\hline Sucrose & - & + & + \\
\hline Xylose & - & + & + \\
\hline \multicolumn{4}{|l|}{$\begin{array}{l}\text { Growth on sole nitrogen sources } \\
(0.1 \%, \mathrm{w} / \mathrm{v}) \text { : }\end{array}$} \\
\hline L-Hydroxyproline & - & + & + \\
\hline L-Methionine & - & + & + \\
\hline Growth pH & $5-9$ & $5-11$ & $5-9$ \\
\hline $\mathrm{NaCl}$ tolerance $(\%, \mathrm{w} / \mathrm{v})$ & $0-3$ & $0-4$ & $0-3$ \\
\hline \multicolumn{4}{|l|}{ API 20E: } \\
\hline Citrate & - & - & + \\
\hline Urease & - & - & + \\
\hline Gelatin & + & - & + \\
\hline Mannitol & - & \pm & + \\
\hline Rhamnose & \pm & + & + \\
\hline Melibiose & - & + & + \\
\hline Amygdalin & - & + & + \\
\hline Nitrate & + & - & + \\
\hline API ZYM: & + & - & + \\
\hline Esterase & - & + & + \\
\hline Valine arylamidase & + & - & - \\
\hline Cystine arylamidase & + & - & - \\
\hline$\beta$-Glucuronidase & - & - & + \\
\hline$\alpha$-Mannosidase & - & + & + \\
\hline \multicolumn{4}{|l|}{ Antimicrobial activity against: } \\
\hline Bacillus pumilus NRRL BD-142 & + & - & - \\
\hline Staphylococcus aureus ATCC 33862 & + & - & - \\
\hline
\end{tabular}

ester peaks were analysed using software version TSBA 50. The DNA G + C content of strains $\mathrm{A} 4029^{\mathrm{T}}$ was determined following the procedure developed by Gonzalez \& SaizJimenez (2005).

Whole-organism hydrolysates of the organism were rich in meso-diaminopimelic acid, xylose and arabinose (wall chemotype II; Lechevalier \& Lechevalier, 1970) and phosphatidylethanolamine, diphosphatidylglycerol, phosphatidylglycerol, phosphatidylinositol, phosphatidylinositol mannosides and different aminophospholipids, phospholipids and glycolipids (phospholipid type II sensu Lechevalier et al., 1977) (Supplementary Fig. S1, available in IJSEM Online). The predominant menaquinone of strain $\mathrm{A} 4029^{\mathrm{T}}$ was MK-9( $\left.\mathrm{H}_{4}\right)(56 \%)$, although substantial amounts of MK-9 $\left(\mathrm{H}_{6}\right)$, MK-9 $\left(\mathrm{H}_{8}\right)$ and MK- $8\left(\mathrm{H}_{4}\right)(18,6$ and $5 \%$, respectively) were present. The major cellular fatty acids were iso- $\mathrm{C}_{15: 0}(21.1 \%)$, anteiso- $\mathrm{C}_{15: 0}(30.3 \%)$, iso- $\mathrm{C}_{16: 0}$ $(11.7 \%), \mathrm{C}_{17: 1} \omega 9 c(7.0 \%)$ and iso- $\mathrm{C}_{14: 0}(7.0 \%)$. Detailed fatty acid profiles are given in Supplementary Table S1 (available in IJSEM Online). The $\mathrm{G}+\mathrm{C}$ content of the DNA is $70.2 \mathrm{~mol} \%$.

It is clear from the genotypic and phenotypic data presented here that strain $\mathrm{A} 4029^{\mathrm{T}}$ represents a novel species in the genus Actinoplanes, for which the name Actinoplanes abujensis sp. nov. is proposed.

\section{Description of Actinoplanes abujensis sp. nov.}

Actinoplanes abujensis (a.bu.jen'sis. N.L. masc. adj. abujensis of or belonging to Abuja, Nigeria, source of the organism).

Aerobic, Gram-positive actinomycete. Colony surface is rough; marginal areas are divided into radial and concentric sections. Cells grow well on ISP 2, ISP 3, ISP 5, ISP 7, GYME medium and MBA. Colour of substrate mycelium is orange on several tested media. A strong brown, soluble pigment is formed on ISP 7. Growth occurs at pH $5-9$ and $20-37{ }^{\circ} \mathrm{C}$, but not at $\mathrm{pH} 10.0$ or $45{ }^{\circ} \mathrm{C}$. Optimal growth is at $25-30{ }^{\circ} \mathrm{C}$ and $\mathrm{pH}$ 7.0. Growth is observed in $0-3 \% \mathrm{NaCl}$ but not $4 \%$ $\mathrm{NaCl}(\mathrm{w} / \mathrm{v})$. Positive for acid phosphatase, alkaline phosphatase, $\alpha$-galactosidase, $\beta$-galactosidase, $\alpha$-glucosidase, $\beta$ glucosidase, catalase, chymotrypsin, cystine arylamidase, esterase lipase, gelatin, leucine arylamidase, $N$-acetyl- $\beta$ glucosaminidase, naphthol-AS-BI-phosphohydrolase, trypsin, valine arylamidase and nitrate reduction; negative for arginine dihydrolase, esterase, lipase, $\alpha$-fucosidase, $\alpha$-mannosidase, $\beta$-glucuronidase, lysine decarboxylase, ornithine decarboxylase, indole and $\mathrm{H}_{2} \mathrm{~S}$ production. Aesculin and arbutin are hydrolysed but not allantoin. Casein and starch are degraded, but not adenine, chitin, elastin, guanine, hypoxanthine, Tweens 20 and 80, DNA, RNA, uric acid, xanthine or xylan. $\mathrm{D}(-)$ Cellobiose, $\mathrm{D}(+)$ glucose, $\mathrm{D}(-)$ mannose, maltose and starch are utilized as sole carbon and energy sources, but not adonitol, amygdalin, $\mathrm{D}(-)$ arabinose, $\mathrm{D}(-)$ fructose, $\mathrm{D}(-)$ galactose, $\mathrm{D}(+)$ melibiose, $\mathrm{D}(-)$ salicin, dextrin, inulin, $\mathrm{D}(+)$ sorbitol, $\mathrm{L}(-)$ sorbose, lactose, $\mathrm{L}-$ glutamate, mannitol, myo-inositol, raffinose, sucrose, xylitol or xylose. Utilizes $\alpha$-isoleucine, D-phenylalanine, glycine, L-alanine, L-arginine, L-proline, L-serine, L-threonine, Ltyrosine and L-valine as sole nitrogen sources, but not Lcysteine, L-histidine, L-hydroxyproline or L-methionine. Antimicrobial activity is shown against Bacillus pumilus NRRL BD-142, Listeria monocytogenes ATCC 19117, Staphylococcus aureus ATCC 33862 and Staphylococcus aureus ATCC 25923, but not against Aspergillus flavus NRRL $1957^{\mathrm{T}}$, Aspergillus parasiticus NRRL 465, Bacillus 


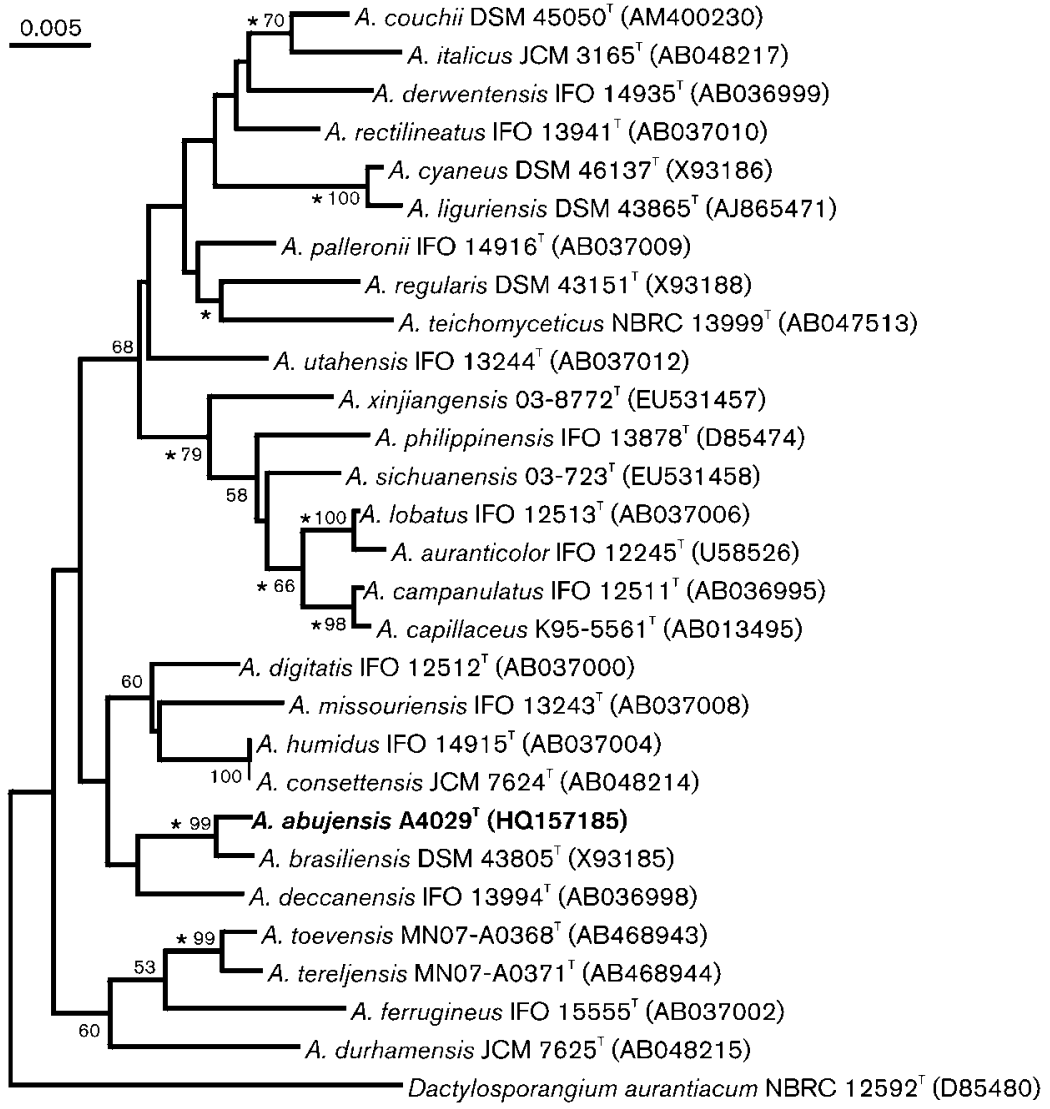

Fig. 1. Neighbour-joining tree (Saitou \& Nei, 1987) based on almost complete 16S rRNA gene sequences showing relationships between strain $\mathrm{A} 4029^{\top}$ and members of the genus Actinoplanes. Asterisks indicate branches of the tree that were also recovered using the maximum-likelihood (Felsenstein, 1981) and maximum-parsimony (Kluge \& Farris, 1969) tree-making algorithms. Numbers at the nodes indicate the levels of bootstrap support (\%); only values above $50 \%$ are cited. GenBank accession numbers are given in parentheses. Bar, 0.005 substitutions per site. The root position of the neighbour-joining tree was obtained using the sequence of Dactylosporangium aurantiacum NBRC $12592^{\top}$ as the outgroup. cereus NRRL B-3711 ${ }^{\mathrm{T}}$, Bacillus licheniformis NRRL B-1001, Candida albicans ATCC 10231, Escherichia coli ATCC 25922, Micrococcus luteus NRRL B-1018, Pseudomonas aeruginosa NRRL B-2679, Proteus vulgaris NRRL B-123, Saccharomyces cerevisiae ATCC 9763 or Streptomyces murinus ISP $5091^{\mathrm{T}}$. The quinone system consists of $\mathrm{MK}-9\left(\mathrm{H}_{4}\right)(56 \%)$, MK$9\left(\mathrm{H}_{6}\right)(18 \%)$ and some minor menaquinones. The polar lipid profile contains phosphatidylethanolamine, diphosphatidylglycerol, phosphatidylglycerol, phosphatidylinositol and phosphatidylinositol mannosides. Major fatty acids are iso- $\mathrm{C}_{15: 0}$, anteiso- $\mathrm{C}_{15: 0}$, iso- $\mathrm{C}_{16: 0}, \mathrm{C}_{17: 1} \omega 9 c$ and $\mathrm{C}_{14: 0}$.

The type strain, A4029 ${ }^{\mathrm{T}}\left(=\mathrm{DSM} 45518^{\mathrm{T}}=\mathrm{NRRL}\right.$ B- $24835^{\mathrm{T}}$ $=$ KCTC $19984^{\mathrm{T}}$ ), was isolated from arid soil in Abuja, Nigeria. The $\mathrm{G}+\mathrm{C}$ content of genomic DNA of the type strain is $70.2 \mathrm{~mol} \%$.

\section{Acknowledgements}

This research was supported by Ondokuz Mayis University (OMU), project no. PYO. FEN. 1901.09.003.

\section{References}

Cashion, P., Holder-Franklin, M. A., McCully, J. \& Franklin, M. (1977). A rapid method for the base ratio determination of bacterial DNA. Anal Biochem 81, 461-466.
Chun, J. \& Goodfellow, M. (1995). A phylogenetic analysis of the genus Nocardia with 16S rRNA gene sequences. Int J Syst Bacteriol 45, 240-245.

Chun, J., Lee, J.-H., Jung, Y., Kim, M., Kim, S., Kim, B. K. \& Lim, Y. W. (2007). EzTaxon: a web-based tool for the identification of prokaryotes based on $16 \mathrm{~S}$ ribosomal RNA gene sequences. Int J Syst Evol Microbiol 57, 2259-2261.

Couch, J. N. (1950). Actinoplanes. A new genus of the Actinomycetales. J Elisha Mitchell Sci Soc 66, 87-92.

De Ley, J., Cattoir, H. \& Reynaerts, A. (1970). The quantitative measurement of DNA hybridization from renaturation rates. Eur $J$ Biochem 12, 133-142.

Felsenstein, J. (1981). Evolutionary trees from DNA sequences: a maximum likelihood approach. J Mol Evol 17, 368-376.

Felsenstein, J. (1985). Confidence limits on phylogenies: an approach using the bootstrap. Evolution 39, 783-791.

Felsenstein, J. (1993). PHYLIP (phylogeny inference package) version 3.5.1. Distributed by the author. Department of Genome Sciences, University of Washington, Seattle, USA.

Fitch, W. M. (1971). Toward defining the course of evolution: minimum change for a specific tree topology. Syst Zool 20, 406-416.

Gauze, G. F., Preobrazhenskaya, T. P., Kudrina, E. S., Blinov, N. O., Ryabova, I. D. \& Sveshnikova, M. A. (1957). Problems of Classification of Actinomycetes-Antagonists. Moscow: Government Publishing House of Medical Literature.

Gonzalez, J. M. \& Saiz-Jimenez, C. (2005). A simple fluorimetric method for the estimation of DNA-DNA relatedness between closely related microorganisms by thermal denaturation temperatures. Extremophiles 9, 75-79. 
Goodfellow, M. \& Cross, T. (1984). Classification. In The Biology of the Actinomycetes, pp. 7-164. Edited by M. Goodfellow, M. Mordarski \& S. T. Williams. London: Academic Press.

Goodfellow, M., Alderson, G. \& Lacey, J. (1979). Numerical taxonomy of Actinomadura and related actinomycetes. J Gen Microbiol 112, 95-111.

Goodfellow, M., Stanton, L. J., Simpson, K. E. \& Minnikin, D. E. (1990). Numerical and chemical classification of Actinoplanes and some related actinomycetes. J Gen Microbiol 136, 19-36.

Hsu, S. C. \& Lockwood, J. L. (1975). Powdered chitin agar as a selective medium for enumeration of actinomycetes in water and soil. Appl Microbiol 29, 422-426.

Huß, V. A. R., Festl, H. \& Schleifer, K. H. (1983). Studies on the spectrophotometric determination of DNA hybridization from renaturation rates. Syst Appl Microbiol 4, 184-192.

Jones, K. L. (1949). Fresh isolates of actinomycetes in which the presence of sporogenous aerial mycelia is a fluctuating characteristic. J Bacteriol 57, 141-145.

Jukes, T. H. \& Cantor, C. R. (1969). Evolution of protein molecules. In Mammalian Protein Metabolism, vol. 3, pp. 21-132. Edited by H. N. Munro. New York: Academic Press.

Kämpfer, P. \& Kroppenstedt, R. M. (1996). Numerical analysis of fatty acid patterns of coryneform bacteria and related taxa. Can $J$ Microbiol 42, 989-1005.

Kämpfer, P., Huber, B., Thummes, K., Grün-Wollny, I. \& Busse, H. J. (2007). Actinoplanes couchii sp. nov. Int J Syst Evol Microbiol 57, 721724.

Kelly, K. L. (1964). Inter-Society Color Council - National Bureau of Standards Color Name Charts Illustrated with Centroid Colors. Washington, DC: US Government Printing Office.

Kluge, A. G. \& Farris, J. S. (1969). Quantitative phyletics and the evolution of anurans. Syst Zool 18, 1-32.

Kothe, H. W. (1987). Die Gattungen Actinoplanes und ihre Stellung innerhalb der Actinomycetales. PhD thesis, University of Marburg, Marburg, Germany.

Kroppenstedt, R. M. \& Goodfellow, M. (1991). The family Thermomonosporaceae. In The Prokaryotes, 2nd edn, pp. 1085-1114. Edited by A. Balows, H. G. Trüper, M. Dworkin, W. Harder \& K. H. Schleifer. New York: Springer.

Kumar, S., Tamura, K. \& Nei, M. (2004). MEGA3: Integrated software for Molecular Evolutionary Genetics Analysis and sequence alignment. Brief Bioinform 5, 150-163.

Lechevalier, M. P. \& Lechevalier, H. A. (1970). Chemical composition as a criterion in the classification of aerobic actinomycetes. Int J Syst Bacteriol 20, 435-443.

Lechevalier, M. P., De Bièvre, C. \& Lechevalier, H. A. (1977) Chemotaxonomy of aerobic actinomycetes: phospholipid composition. Biochem Syst Ecol 5, 249-260.
Mikami, H. \& Ishida, Y. (1983). Post-column fluorometric detection of reducing sugars in high-performance liquid chromatography using arginine. Bunseki Kagaku 32, E207-E210.

Minnikin, D. E., O’Donnell, A. G., Goodfellow, M., Alderson, G., Athalye, M., Schaal, A. \& Parlett, J. H. (1984). An integrated procedure for the extraction of bacterial isoprenoid quinones and polar lipids. J Microbiol Methods 2, 233-241.

Nash, P. \& Krenz, M. M. (1991). Culture media. In Manual of Clinical Microbiology, 5th edn, pp. 1226-1288. Edited by A. Balows, W. J. Hauser, K. L. Herrmann, H. D. Isenberg \& H. J. Shadomy. Washington, DC: American Society for Microbiology.

Saitou, N. \& Nei, M. (1987). The neighbor-joining method: a new method for reconstructing phylogenetic trees. Mol Biol Evol 4, 406425.

Sasser, M. (1990). Identification of bacteria by gas chromatography of cellular fatty acids, MIDI Technical Note 101. Newark, DE: MIDI Inc.

Shirling, E. B. \& Gottlieb, D. (1966). Methods for characterization of Streptomyces species. Int J Syst Bacteriol 16, 313-340.

Staneck, J. L. \& Roberts, G. D. (1974). Simplified approach to identification of aerobic actinomycetes by thin-layer chromatography. Appl Microbiol 28, 226-231.

Tamura, T. \& Hatano, K. (2001). Phylogenetic analysis of the genus Actinoplanes and transfer of Actinoplanes minutisporangius Ruan et al. 1986 and 'Actinoplanes aurantiacus' to Cryptosporangium minutisporangium comb. nov. and Cryptosporangium aurantiacum sp. nov. Int $J$ Syst Evol Microbiol 51, 2119-2125.

Thompson, J. D., Higgins, D. G. \& Gibson, T. J. (1994). CLUSTAL W: improving the sensitivity of progressive multiple sequence alignment through sequence weighting, position-specific gap penalties and weight matrix choice. Nucleic Acids Res 22, 4673-4680.

Tindall, B. J. (1990a). A comparative study of the lipid composition of Halobacterium saccharovorum from various sources. Syst Appl Microbiol 13, 128-130.

Tindall, B. J. (1990b). Lipid composition of Halobacterium lacusprofundi. FEMS Microbiol Lett 66, 199-202.

Vobis, G. (1989). The Actinoplanetes. In Bergey's Manual of Systematic Bacteriology, vol. 4, pp. 2418-2428. Edited by S. T. Williams, M. E. Sharpe \& J. G. Holt. Baltimore: Williams \& Wilkins.

Wayne, L. G., Brenner, D. J., Colwell, R. R., Grimont, P. A. D., Kandler, O., Krichevsky, M. I., Moore, L. H., Moore, W. E. C., Murray, R. G. E. \& other authors (1987). International Committee on Systematic Bacteriology. Report of the ad hoc committee on reconciliation of approaches to bacterial systematics. Int J Syst Bacteriol 37, 463-464.

Williams, S. T., Goodfellow, M., Alderson, G., Wellington, E. M. H., Sneath, P. H. A. \& Sackin, M. J. (1983). Numerical classification of Streptomyces and related genera. J Gen Microbiol 129, 1743-1813.

Wu, C., Lu, X., Qin, M., Wang, Y. \& Ruan, J. (1989). Analysis of menaquinone compound in microbial cells by HPLC. Microbiology [English translation of Microbiology (Beijing)] 16, 176-178. 